SISTEMA
ELETRÔNICO
DE REVISTAS
SER I UFPR

\title{
Chico Mendes, the rubber tappers and the Indians: reimagining conservation and development in the Amazon
}

\section{Chico Mendes, os seringueiros e os índios: reimaginando conservação e desenvolvimento na Amazônia}

\author{
Stephan SCHWARTZMAN ${ }^{1^{*}}$ \\ ${ }^{1}$ Environmental Defense Fund, Washington DC, U.S.A. \\ *E-mail of contact: steves@edf.org
}

Article received in April 9, 2018, final version accepted in August 13, 2018.

ABSTRACT: In the mid-1970's rubber tapper leaders Chico Mendes and Wilson Pinheiro reformulated strategic objectives of the rubber tappers' movement, from protesting and denouncing violent dispossession of families and deforestation to defending rubber tappers' forest territories and diversified land use. This strategic turn laid the basis for the rubber tappers' transformation from a solely class-based union movement to one that incorporates a specific cultural identity associated with land and resource uses defined as opposed to the government-sponsored socio-environmentally destructive development model. The rubber tappers' conceptual transformation of "extractivism", from an archaic, outdated and primitive economic activity into an alternative for a modern, sustainable development model, based in their distinct culture, mirrored and paralleled the emergence of identity-based social movements globally. It also mirrored the re-emergence of "submerged" indigenous ethnicities and subsequent "ethnogenesis" of allegedly extinct or forgotten indigenous peoples, in both cases contrary to the assumptions and predictions of both policy and some anthropological theory. The rubber tappers' definition of extractive reserves as collective land rights - and access to technology, social services and markets on terms in some measure controlled by the communities - in exchange for environmental and forest protection enabled significant territorial gains (parallel to indigenous territories), as well as proliferation of extractive reserve analogues in both environmental and land reform policy. Alliances with indigenous peoples and environmentalists were central to the development of this vision. The model of collective rights, with access to technology, services and markets could have very broad applicability for poor populations globally, in light of climate change and other environmental crises, if at-scale incentives for climate change and other environmental mitigation can be created.

Keywords: Chico Mendes; Amazon; conservation; development. 
RESUMO: $\quad$ Na década de 1970, os líderes seringueiros Chico Mendes e Wilson Pinheiro reformularam os objetivos estratégicos do movimento dos seringueiros, passando de denunciar a expulsão violenta das famílias e o desmatamento, para promover políticas de defesa florestal e de uso diversificado da terra. Essa virada estratégica preparou o terreno para a transformação de um movimento de caráter sindical, expressivo unicamente de uma classe social, em movimento incorporando uma identidade cultural específica associada à um conjunto de recursos, práticas e usos da floresta, em franca oposição ao modelo de desenvolvimento "oficial" patrocinado pelo governo, socioambientalmente destrutivo. A transformação conceitual do "extrativismo", de atividade econômica arcaica à alternativa de desenvolvimento moderna e sustentável, também espelhou o advento de movimentos sociais com identidade global e a emergência de identidades étnicas indígenas "submersas" (etnogenese) supostamente extintas ou esquecidas - em ambos casos contrários aos pressupostos e previsões das políticas públicas em vigor e de parte da teoria antropológica. A consequente definição das "reservas extrativistas" como conceito fundiário portador de direitos coletivos territoriais, tais como acesso à tecnologia, serviços sociais e mercados de alguma forma controlado pelas comunidades, além de oferecer proteção ambiental, possibilitou ganhos territoriais significativos paralelos à expansão do reconhecimento dos territórios indígenas, bem como a multiplicação de figuras análogas às reservas extrativistas nas políticas ambientais e de reforma agrária. As alianças com os povos indígenas e os movimentos ambientalistas foram centrais para o desenvolvimento dessa visão. Quase meio século depois, o modelo seringueiro de direitos coletivos pode tornar-se replicável para populações pobres em escala global, considerando as mudanças climáticas em curso e as crises ambientais contemporâneas, desde que providenciada a necessária criação de incentivos para a mitigação climática.

Palavras-chaves: Chico Mendes; Amazônia; conservação; desenvolvimento.

\section{Introduction}

Chico Mendes' legacy thirty years after his assassination, the theme of this volume, has many dimensions: the trajectory of the National Council of Rubber Tappers and development and expansion of the Extractive Reserves; the history of the Popular Front/Workers' Party state governments in Acre since 1999; the sea change in popular consciousness and public opinion regarding Amazon deforestation in Brazil; the emergence of the socio-environmental movement in Brazil and internationally; and more. I have chosen not to discuss any of these directly, but rather to examine shifts in Chico's political thought and perspectives from the mid-1970s - 1980s that enabled him to project the local struggle of the rubber tappers of the Acre river valley onto Amazonian, national and international stages, and that ultimately led to his multi-dimensional legacy. These innovations contributed to and catalyzed parallel processes in other Amazonian social movements, profoundly changing the political, socio-cultural and ecological landscape of the Amazon.

I have adopted this approach for personal reasons. When I first met Chico Mendes in October of 1985 at the first national meeting of rubber tappers in Brasília, it was my first direct experience of Amazonian rural workers' unions, or indeed any Brazilian union or social movement. I have found that my appreciation of Chico's political brilliance and singularity as a strategic thinker has consistently grown in retrospect, and so I will focus on these aspects of his story.

The article summarizes events leading up to Chico Mendes' emergence as a rural union leader in the 1970's, and the evolution of the rubber tappers' 
movement in the Acre river valley, from protest against violent land conflicts and deforestation, to negotiations with ranchers, and focuses on the strategic turn in 1975 to resistance in the forest and defense of the rubber tappers' landholdings (colocações) and resource use. I use my own and others' interviews with Chico to examine how the development of his political and strategic thinking led from resistance and the empates (direct actions in the forest to stop deforestation) to the emergence of an identity-based social movement through the National Council of Rubber Tappers and Alliance of the Peoples of the Forest. The paper shows how the shift to resistance and rubber tapper identity alienated some previous or potential allies, while making alliance with indigenous peoples and national and international environmentalists possible. I then discuss the emergence or reconstruction of indigenous identities and ethnicities over the same time period as paralleling and mirroring the proliferation of "traditional identities" based in specific land and resource uses, as well as new forms of collective land and resource rights. The paper concludes that the collective rights modality of the "extractive reserves" originally proposed by Chico and the rubber tappers' movement could be, contrary to anthropological and other academic concerns with socially exclusionary effects of the concept of "indigeneity," very broadly applicable to rural and urban poor communities in the context of the global climate change crisis.

\section{Fieldwork}

I first met and interviewed Chico Mendes in Brasília in October, 1985, at the first national meeting of rubber tappers. I then attended the first meeting of the National Council of Rubber Tappers (CNS) in March of 1986 in Rio Branco, Acre, and subsequently travelled to Novo Aripuanã, Amazonas, for the opening of the first delegacy of the rural workers' union of the county in April. From March 22 - April 1, 1987 I accompanied Chico Mendes on his first trip to the United States, to the annual meeting of the Inter-American Development Bank (IDB) in Miami and then in meetings in the US Congress and with civil society organizations in Washington DC. I interviewed Chico about the history of the union movement in Acre on March 29, 1987 in my house in Washington DC. It is my Portuguese transcription of this interview that I cite in this article. In August of 1987 I attended a CNS meeting in Rio Branco, In September of 1987, I accompanied Chico on his second trip to the US, to accept the Better World Society environment award in New York, then in the Congress and IDB in Washington DC. In late October 1987 I travelled to Xapuri, with Paulo Chiesa of the Institute for Amazon Studies, where, with Chico's support, over about ten days we conducted a socio-economic survey of the rubber tappers of Seringal Cachoeira. In September of 1988, I conducted a shorter socio-economic survey in Seringal São Luis de Remanso to test a questionnaire later used by a state government team in support of the creation of an Extractive Settlement Project there. It was probably on this trip that I attended the meeting of the Xapuri Rural Workers' Union in which Chico and other union leaders attempted unsuccessfully to dissuade a rubber tapper from Seringal Cachoeira from selling his colocação to rancher Darly Alves. I also have clear memories but no documentation of visiting rubber estates near the town of Xapuri with Chico, once with a journalist and photographer 
from the St. Louis Post-Dispatch (Figure 1), once to collect material for a rubber tapper diorama in a rainforest exhibition in the Smithsonian Institution, and once to attend a union delegacy meeting, during the occupation of the IBDF in Xapuri protesting illegal deforestation.

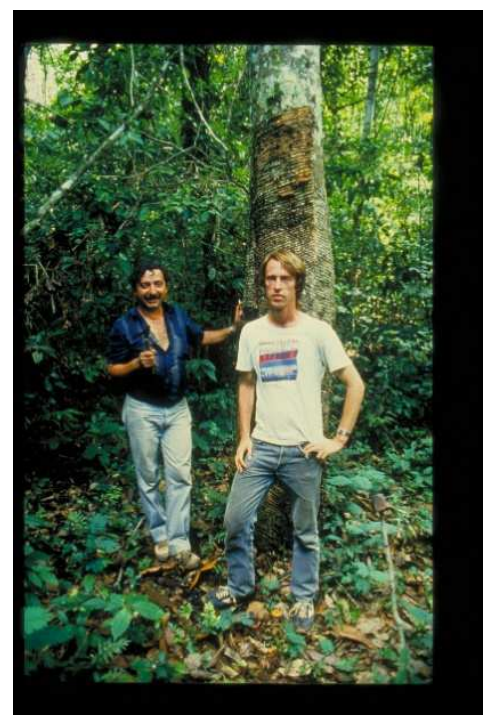

FIGURE 1 - Chico Mendes and Stephan Schwartzman at a rubber estate in Xapuri, Acre in 1987.

\section{Emergence of the Unions in the Acre River Valley}

Chico's early political education and organizing are amply documented in several sources, starting with his own account (Mendes \& Gross, 1989; Mendes \& Gryzbowski, 1989; Allegretti, 2002). Grandson of a Cearense who fled the drought in northeastern Brazil for the rubber estates of Acre, as an adolescent in the rubber estates of Xapuri, Acre, Chico was befriended by a southern Brazilian communist and fugitive political prisoner, Euclides
Távora, who taught him to read and write in the early 1960s. In the same period, the traditional rubber estates in the Acre river valley, in which rubber estate bosses, or "patrons" dominated their rubber tapper clients in a debt bondage (barracão) system, collapsed along with rubber prices. Rubber tappers were then free to plant gardens, hunt and fish, collect Brazil nuts, and sell their rubber and Brazil nuts to travelling merchants. Chico would later characterize the end of the traditional rubber estates as the first phase of the rubber tappers' struggle.

By 1970 however, the federal government had built the 317 highway from the state capital of Rio Branco to Assis Brasil on the Peruvian border, and offered subsidies to ranchers to acquire and clear the old rubber estates - although these were still occupied by rubber tappers. Conflicts proliferated, and through the appeals of the local Catholic Church, in 1973 the National Confederation of Agricultural Workers (CONTAG) began union organizing in Acre, and began to promote negotiations over the conflicts. Disputed rubber estates were divided between rubber tappers and ranchers, and some rubber tappers were indemnified for improvements to their land. The national land agency, INCRA, subdivided some estates, giving rubber tappers 50 or 100 hectare lots, laid out on a rectangular grid - utterly disrupting rubber tappers' resource use patterns, on the assumption that they would - indeed, should -- become small-scale family farmers. In these situations, many rubber tappers saw no choice but to leave the forest for urban peripheries -- and lives of penury. Others fled to Bolivia in search of intact rubber estates. It was under these circumstances that in 1975 CONTAG formed the first rural workers' unions, and Chico became a union leader. 


\section{Resistance in the Forest}

Mary Allegretti, in an original, highly synthetic article written ten years after Chico's murder, traces the key change that would lead to Chico's emergence as an international figure to this moment (Allegretti, 1998). Chico and Brasileia rural workers' union president Wilson Pinheiro (murdered in 1980) recognized that CONTAG's legal agreements and indemnifications allowed deforestation to continue, depriving the rubber tappers of the sources of their livelihoods, which could not easily be replaced in the city. Small-scale farming without access to markets, credit or technical assistance could not make up for even limited cash income from rubber and Brazil nuts, still less for the loss of forest resources entailed by the destruction of the rubber estates. They defined a new strategy - "to stop forest clearing and continue living in the forest" (Allegretti, 1998, p. 7). They conceived the non-violent demonstrations to halt deforestation called "empates" for which Chico would eventually become famous, as the tactical means to implement this strategy, and the first was held in Seringal Carmen in Brasiléia in 1976. In retrospect, it is clear that the subsequent major initiatives Chico undertook and innovations he launched - the proposal for differential land reform for rubber tappers at the $4^{\circ}$ National Congress of CONTAG in 1984, local education projects, the first national meeting of rubber tappers, extractive reserves, the alliance of the peoples of the forest, and alliance with environmental movements - grew out of this strategic turn, when Chico and Wilson Pinheiro resolved that denouncing and temporarily interrupting violence alone was insufficient to what became the core goal of defending the distinctive forest-based way of life of the rubber tappers. Chico clearly understood this turn as an inflection point, as he recalled in 1987 ,

“. . . then the first confrontations, face-offs, started, we found a way to block the advance of deforestation. I remember that the first 'empate't that happened in Acre was in May of 1976 on a ranch in the county of Brasiléia, where 60 rubber tappers corralled the rancher's workers for three days in an area that was about to be deforested. This had very great repercussions, it drew the attention of the police and the army, as well as involving the federal police. All of a sudden a commission from CONTAG arrived on the scene, and there began the first agreements. The rubber tappers entered into these agreements from a low level of political consciousness, but this was still a great step forward. This time, the people were not driven out, they forced the ranchers to give each one a little piece of land. This was in 76. Of course this wasn't a victory because the important thing is to conserve the colocações [the forest areas worked and inhabited by rubber tapper families $]^{2}$. But this started a process that matured little by little. We discovered as time went on, the process, the advance in consciousness that what was important wasn't making agreements with the ranchers and getting a piece of land. What was important was to struggle for the conservation of our forest, the defense of the rubber trees, and finally the defense of our landholdings. So that, from 77, 78, 79 there were extremely dangerous moments of confrontation, because our position was for actual defense, to not let the rubber trees get cut down and not accept little pieces of land, because afterwards we perceived that the first agreements that were made, the companheiros ${ }^{3}$ who received a piece of land, it didn't even take two years and they were already selling it to the rancher, because they couldn't adapt to that system of work [small-scale family agriculture]. The guy had a colocação with $3,4,5,6$ rubber trails, ${ }^{4}$ he made rubber and

\footnotetext{
1 "Empates" were non-violent demonstrations in which rubber tappers, including women and children, confronted or surrounded ranchers' workers in the forest to persuade or prevent them from proceeding with deforestation.

${ }^{2}$ A "colocação" (literally "a putting, placement") in traditional rubber estates was the area within a rubber estate to which the patron assigned rubber tappers to live and work, defined by occurrence of rubber trees. Each colocação typically had between three and six "rubber trails," looping paths connecting hundreds of rubber trees in the forest, radiating from the rubber tapper's house in the center.
} 
there was no lack money for things. All of a sudden, the minute he has a little piece of land the situation changed, he didn't have money to buy medicine or to buy clothes because that system of work was no good for him. In the market and in the city it was no better, the government provided no support, just like today. They despaired and left for the cities or to look for colocações in the rubber estates of Bolivia. So, the movement grew and matured more from 79 to now when the rubber tappers took a different position. It didn't work to accept a little piece of land, it didn't help. This is a disaster for us. What we need to do is defend the colocações and the rubber tree, with which we are preserving the forest as well, as we've done for so many years and this is what we need to continue to do. With this we've succeeded in greatly slowing the devastation of the region ..." (interview with Chico Mendes, March 29 ${ }^{\text {th }}, 1987$, Washington DC, p.3. My translation).

This strategic turn from protesting, but ultimately accepting the deforestation of the rubber estates and destruction of the colocações and negotiating for indemnification or land, to the defense of the rubber tappers' specific form of land and resource use, heightened the conflicts, as Chico notes. Wilson Pinheiro, several other leaders and ultimately Chico were murdered at the behest of ranchers. It also appears to have set Chico, Wilson Pinheiro and those aligned with them at odds with some who had supported the rubber tappers movement, although the motivation for these differences is largely only discernable indirectly.

Other sectors of the union movement - those based in colonist-farmer populations, and those less politicized, or less aware of the progressive Catholic Church teachings under "liberation theology" - were operating on different assumptions, and did not endorse the turn towards resistance. According to Chico, "They [the state Federation of Agriculture Workers (FETAG), composed of representatives of all of the county-level rural workers' unions] have been very slow and shaky in this process, because they prefer the negotiation game, to sit down with the ranchers and try to negotiate, or to seek out the authorities in a very humiliating way. They think they have to bow down before the authorities and implore. . . The rubber tapper to this day only ever achieved anything on the basis of actual resistance." (Interview with Chico Mendes, March 29 $9^{\text {th }}, 1987$, Washington DC, my translation. See also Allegretti, 2002, p. 489-490 for FETAG-AC's accusations against Chico in 1986). Chico similarly criticized what he regarded as CONTAG's tepid response to the assassination of Wilson Pinheiro in 1980.

Even the Catholic Church, a critical source of support for the rubber tappers at the outset of the conflicts, through the organizing of Ecclesiastical Base Communities, was hesitant to support unqualified resistance, probably either for fear of aggravating the conflicts, or because of the assumption that "extrativismo" was inviable and doomed to disappear. "The relationship with the Church has been important. We have had clashes at some points. We're aware that the Church has had an important role, but it only goes so far, and after a certain point, stops .... for some time, it was a little shaky about this resistance of the rubber tappers".

\footnotetext{
${ }^{3}$ While companheiro can be translated as "comrade" or "companion", the former too directly evokes Soviet communism in American English and the latter lacks the sense of leftist social movement solidarity conveyed in Portuguese.

${ }^{4}$ Estradas de seringa, or "rubber trails" are the basis of the colocação: looping paths through the forest, typically starting and ending at the rubber tapper's house, each running between some dozens of rubber trees.

${ }^{5}$ Liberation theology, developed by Latin American Catholic theologians in the 1950's and 60's, drew on Marxist theory and Catholic theology to develop an activist agenda to address pervasive poverty and social injustice. Its principal organizing strategy in Brazil was the "Ecclesiastical bae Communities," local grassroots groups modeled on the collective way of life of Jesus' disciples, informed by Marxist analysis of local socio-economic and political issues.
} 
(Mendes \& Grzybowski, 1989, p. 50). We can infer from this that the Church thought that negotiations were a wiser course.

It was largely the conceptual innovation of claiming a rubber tapper identity, distinct from and in addition to a class identity, (possibly in addition to fear of heightened conflicts with the ranchers), that provoked the negative reactions Chico noted. Defending the colocações and proposing the extractive reserves that grew out of this strategy involved much more than an instrumental means of winning land conflicts, important though this was. An episode from CNS's first round of high level federal government meetings in Brasília in January of 1987 illustrates this point. A delegation of indigenous leaders from Acre, the directorate of the CNS, Chico, as president of the Xapuri Rural Workers Union and several advisors conducted a series of meetings to announce the new Alliance of the Peoples of the Forest between the Union of Indigenous Nations (UNI) and the CNS, and advocate both for demarcation of indigenous lands and for the new proposal for the creation of Extractive Reserves for rubber tappers. Among other meetings, the group was received by then Minister of Culture Celso Furtado - a leading economist of development and underdevelopment, highly regarded public intellectual, and former political exile. Mary Allegretti writes of the occasion,

"While for the indigenous and rubber tapper leaders, this was just another meeting, for the advisors it was an opportunity to personally meet someone whose books everyone had studied at the university. They expected to encounter a strong ally for the Extractive Reserves. The opening speech of the leaders emphasized the specificity of the indigenous and rubber tapper cultures and the role of both in the defense of the natural patrimony of the Amazon. Celso Furtado accepted the indigenous leaders' arguments, but contested those of the rubber tappers. He affirmed that no extractivist culture existed because this was one of the most primitive activities of humanity, which was in the most elementary stages of human progress, the overcoming of which was an inevitable condition of development. The reaction of everyone was immediate, affirming that there was a culture of the forest, that they were not primitives, they sought means to improve incomes and productivity, but that they did not think that progress meant leaving the forest" (Allegretti, 2002, p. 535).

Many of the rubber tappers' interlocutors harbored similar assumptions about extractivism and the inexorable historical process which would bring it to an end, which led them to underestimate the rubber tappers' political and strategic capacity. Historian Élio Garcia Duarte, recounts the results of the $1^{\text {st }}$ Meeting of Rubber Tappers of Xapuri (immediately preceding the first national meeting of rubber tappers in October 1985), including a telling "motion of repudiation of the Regional Plan for Agrarian Reform (PRRA)" recently approved by federal agencies. The PRRA - a land reform policy formulated by leftists in the Agrarian Reform Ministry -- proposed a position on extractivism: "To promote a land use and occupation model that allows the gradual transition from extensive extractivism ${ }^{6}$ to agriculture and extraction from plantations." The Xapuri rubber tappers regarded this as tantamount to siding with the ranchers against them, and denounced the plan as a betrayal (Duarte, 1987, p. 117). In sum, the development of capitalist agriculture, or indeed modernity more broadly, in this view tended far more toward making forest peoples a marginalized farming peasantry or urban

\footnotetext{
${ }^{6}$ Extractivism in the context of Amazon forest peoples refers to commercial collecting of non-domesticated products, such as tapping native rubber trees, collecting Brazil nuts, etc., not to mineral extraction.
} 
proletariat than enabling prosperous, sustainable forest communities.

The same view of extractivism as a backward, archaic form of economic activity (and thus an inadequate basis for forest protection) has resurfaced repeatedly over the years in relation to the extractive reserves. An extensive literature has predicted (or declared) the demise of the extractive reserves as a forest conservation strategy on the grounds that extractivism is inefficient, non-competitive in the market and thus doomed to disappear, leaving the extractivists with no means of support (Browder, 1992; Terborg, 1999; Homma 2012). But it is a fundamental misconception to imagine that rubber tappers or ribeirinhos (traditional riverine communities, who inhabit extractive reserves in Pará and other regions of the Amazon) oppose deforestation and want to stay in the forest based only or even largely on market-economic self-interest, much less on a naïve belief in the market-economic viability of traditional extractivism. Rubber tapper and $\mathrm{ri}$ beirinho identities are based on knowledge and use of highly diverse forest ecosystems and resources (Villas-Boas et al., 2017). Not having to depend on money for more than a relatively small part of one's sustenance can be seen as advantageous (Schwartzman, 2018). A sense of belonging in certain places may also carry substantial weight (Zarin, 2010). All of these factors were no doubt in play when, after the three extractive reserves of the Terra do Meio, in the Xingu river basin, were created from 2006 - 2008, Instituto Socioambiental (ISA) project staff conducted surveys with the ribeirinho reserve residents about prospects for the future. Many of the ribeirinhos voiced the desire to return to tapping native rubber - an activity that had ceased some thirty years before when prices crashed and local patrons left. As in Acre, ex-rubber tappers in the Terra do Meio describe the traditional rubber estate/barracão system as "captivity" or "slavery", but also have a deep connection to and pride in the activity (Villas Boas et al., 2017). Recall Chico's remarks on the importance of the defense of the colocação: "the [rubber tapper] has a colocação . .. he makes rubber and doesn't lack money to buy things" (pp. 5 - 6, above). This, in reference to a period in which rubber prices were so low that the old "owners" of the rubber estates had abandoned them. Implicit in and central to Chico's statement is the whole complex of forest resources, local knowledge and vernacular management practices made up by the colocação - not only rubber and Brazil nuts, but fish, game, medicinal plants, materials for housing and household artifacts, palm nuts, natural oils, etc. There is no lack of money to buy things, because the rubber tapper has a colocação and so meets large part of her needs outside of the market.

If the option for resistance and defense of the colocação was viewed as radical or unrealistic by some potential or provisional allies, it opened up entirely new possibilities of alliance for the rubber tappers. Once Chico and the Xapuri union, building on the distinct identity they had developed defending their resource base, proposed a national meeting of rubber tappers, the affinities and similarities between indigenous peoples and rubber tappers quickly became apparent. The central proposal of the rubber tappers' movement articulated at the first national meeting of rubber tappers in Brasília, in October 1985, the "extractive reserve," explicitly expressed rubber tappers' identification with the indigenous peoples. The idea was initially conceived by rubber tappers from Rondônia based on their observations of the demarcation of 
indigenous reserves and their experience of rapid deforestation with paving of the BR 364 highway and government-sponsored agriculture colonization. Although the rubber tappers in Rondônia were largely not unionized, with rapid deforestation and division by INCRA of extensive areas of forest into lots for colonization projects, they entirely shared the Acre rubber tappers' concern with maintaining the rubber estates and securing rubber tappers' land and resource use patterns. In two separate county-level meetings in preparation for the National Encounter, rubber tappers proposed the creation of reserves like indigenous reserves for rubber tappers: “. . . the Indians have the right to an area, a forest reserve for the Indians, and the rubber tapper ought to have a forest reserve for the rubber tappers ..." (Allegretti, 2002, p. 398). In summary documents of the Rondônia meetings, these proposals were called "extractive reserves."

The rubber tappers' relations with indigenous peoples went beyond the reserve concept. Immediately following the $1^{\text {st }}$ National Meeting of Rubber Tappers, CNS President Jaime da Silva Araújo went to São Paulo in response to invitations secured by filmmaker Adrian Cowell to address the United Nations World Commission on Environment and Development, which was then beginning preparations for the 1992 UN Conference on Environment and Development. Union of Indigenous Nations President Ailton Krenak also addressed the WCED, and both referenced the affinity between Indians and rubber tappers in their remarks (Allegretti 2002, p. 426-427 reproduces both statements). Clearly, the groups shared a fundamental common interest in controlling or halting large-scale deforestation and in securing their respective land rights (Schwartzman, 1986). By January of 1987, CNS and UNI-North region, during a round of meetings with government officials in Brasilia, announced the creation of the Alliance of the Peoples of the Forest (Alegretti 2002, p. 528).

The $1^{\text {st }}$ National Meeting of the Rubber Tappers, the creation of the CNS and the extractive reserves proposal are amply documented and discussed elsewhere (Allegretti, 2002; Cunha \& Almeida, 2004). I want to highlight three points that Chico regularly characterized as political advances in his post- 1985 political analyses and discourse the creation of the CNS and the extractive reserves proposal; alliance with international environmental organizations; and alliance with the indigenous peoples. Chico often linked the three:

"I'd like to talk a lot more about the situation today. . . I think the [CNS] emerged with the advance of the rubber tappers' struggle, it demonstrates in practice that we're capable of doing a lot and of striking fear into the powerful. I think ... the alliance - that people didn't expect - between Indians and rubber tappers, that is between CNS and UNI, is the most important step we've taken in many years. And it's not just that, because inasmuch as we were able to move our struggle forward, our level of consciousness advanced. There's a third example, it's the alliance that we're beginning to have, our contacts with international organizations. Who would ever have thought about these things ten or even five years ago? No one ever thought about these things. This contributed a lot to the advance, even those rubber tappers who over time in the movement, with the deficiencies in our struggle, retreated, lost hope. Today, these people are already starting to take heart as they discover that there is an immense amount of support" (Interview with Chico Mendes, March 29, 1987, Washington DC, p. 9. My translation).

Chico explicitly linked the rubber tapper identity with the CNS, alliance with the Indians, and the broader program of defense of the forest that enabled alliance with environmental movements: 
"The CNS is not meant to be a kind of parallel trade union, replacing the Xapuri Rural Workers' Union, for example. It is just an organization for rubber tappers. The growth of the trade unions was very important for us ... other kinds of agricultural workers have been seen as having particular needs and interests, but not rubber tappers; it's as though we were something that existed only in the past. So one of the reasons for creating the CNS was to recognize the rubber tappers as a particular group of workers fighting for a very important objective - the defense of the Amazon forest. ... We also wanted to seek out the leaders of the Indian peoples in Acre and discuss how to unite our resistance movements, especially since Indians and rubber tappers have been at odds for centuries ... from the beginning of 1986 our alliance has gotten stronger and stronger. . . Our proposals are not just ours alone, they are put forward together by Indians and rubber tappers. Our fight is the fight of all the peoples of the forest." (Mendes and Gross, 1989, p. 46)

"I believe the rubber tappers have advanced much farther with the issue of the extractive reserves, and this has had an impact in Brazil and abroad. I can affirm that what the unions have not done in twelve years, the National Council of Rubber tappers has achieved in less than two" (Interview with Chico Mendes, O Rio Branco, 13/06/87:13, cited in Allegretti 1989, p. 8).

"...my work is directly with the peoples of the forest, that is, the Indians and the rubber tappers." (Mendes, 1988. p. 1).

"Our biggest assets are the international environmental lobby and the international press. I'm afraid we have had more support from abroad than from people in Brazil, and the opposite should be the case. It was only after international recognition and pressure that we started to get support from the rest of Brazil." (Mendes \& Gross, 1989, p. 51)

By 1986, Chico and the CNS leaders had clearly committed to alliance with UNI, nationally and in Acre, and linked this alliance with the understanding that their struggle, prior to 1985 seen as essentially between rural workers and capital, or the latifundio in Acre, was a struggle in defense of the Amazon forest, and with the understanding that deforestation was a global concern. Alliance with the Indians had become part or the rubber tapper's hybrid rural worker/rubber tapper identity, as Ailton Krenak, then National Coordinator of UNI attested in a statement shortly after Chico's murder.

\begin{abstract}
'In the last ten years, the rubber tappers' movement, led by Chico Mendes, had the sensibility to overcome this history of enmity manipulated by the patrons, and lay the groundwork of the current alliance of the peoples of the forest, which Chico summarized like this: 'Our people are the same people, we are no longer white. We have a different culture from the white people and we think differently than the civilizados (civilized people). We learned from the Indians and from the forest how to raise our children. We meet all of our basic needs and we have already created our own culture, which brings us much closer to the indigenous tradition than to tradition of the civilizados. We already know this, now Brazil needs to know this"” (Krenak, et al., 1989 p. 26).
\end{abstract}

The importance of constructing a rubber tapper identity was recognized by at least some of the rubber tappers' and Indians' allies in Chico's lifetime. In September of 1988, the Institute for Amazon Studies (IEA) held a workshop on the Extractive Reserves concept in Curitiba, attended by Chico Mendes, other leaders of the National Council of Rubber Tappers (CNS), researchers and NGOs aligned with the CNS. Anthropologist Carlos Alberto Ricardo, with the Indigenous Peoples in Brazil program of the Ecumenical Center for Documentation and Information (CEDI) made a striking series of comments to the CNS leaders, their advisors and partners. He lauded the group for having "transformed a defect into a virtue" - with the proposal for extractive reserves, the rubber tappers had transformed extrativismo (extractivism ${ }^{7}$ ), typically seen as a backward, outmoded form of production, into an alternative for the future (Carlos Alberto Ricardo, personal communication, Sep- 
tember 12, 1988, Curitiba). He then addressed the rubber tappers, crediting them with having recognized that under the Marxist theory that informed their political organizing, as workers, they could expect to engage in any number of conflicts with the agents of capital. Regardless of the outcome of any given conflict, the same two social classes, labor and capital, would continue to come into conflict until the "revolutionary transformation of society" (Marx \& Engels, 1848, p. 14). As rubber tappers, however, considering the experience of the rubber tappers of the Acre River valley, they could perfectly well disappear as a distinct social category should they lose enough specific conflicts with ranchers. He then credited the group for having "internationalized politics" (in reference to Chico Mendes' trips to the United States and the United Kingdom, and advocacy on local communities' rights and forest protection in collaboration with US environmental groups, directed inter alia at the Inter-American Development Bank). The kind of international political alliance rubber tappers were building, he noted, was new, and important not only for rubber tappers and environmentalists, but for social movements in Brazil and internationally. The extent to which the rubber tappers - largely through Chico Mendes' leadership - had "internationalized politics" would become evident a few short months later, when Chico's assassination ran first on the cover of the New York Times (Simons, 1988), then around the world and became a media storm in Brazil.

The rubber tappers' move from organizing and seeing themselves solely as "workers" or "rural workers" to also organizing and seeing themselves as "rubber tappers", the shift to which Ricardo called attention in 1988, apparently corresponds to a much broader, global, transformation in social movements that sociologist Manuel Castells links to the transformation of capitalism in the second half of the twentieth century, under globalization and the emergence of a global information network: "Along with the transformation of capitalism... We have experienced the widespread surge of powerful expressions of collective identity that challenge globalization and cosmopolitanism on behalf of cultural singularity and peoples' control over their lives and environment." (Castells, 1996, p. 2) The rubber tappers, while continuing to see themselves as workers and participate in labor unions, developed a specific political identity as "rubber tappers" and organized an entirely new social movement, embodied in the National Council of Rubber Tappers, to advance their specific agenda. Chico Mendes, through his leadership of this movement, became "... the first phenomenon of a certain type of globalization; a simple rubber tapper [who] came to be recognized . . . by the world because of his ideas about the Amazon" (Allegretti, 1998, p. 8).

Based in his own and his colleagues' experience of land conflicts, and his extremely acute political judgement, Chico both engineered the transformation of the rubber tappers' movement and gave voice to a diffuse, underlying social process through which rubber tappers from all over the Amazon were coming to see themselves as like Indians. This strategic and ideological turn opened the way to an entirely new and unexpected set of alliances, and put the rubber tappers on a different

\footnotetext{
${ }^{7}$ Extractivism in the context of Amazon forest peoples refers to commercial collecting of non-domesticated products, such as tapping native rubber trees, collecting Brazil nuts, etc., not to mineral extraction.
} 
footing in relation to government agencies as well as their rancher adversaries, but at the same time had the effect of further heightening conflicts and alienating certain previous allies, and some sectors of the academy and environmental movement.

\section{Turning Indian}

The rubber tappers were not the only ones in Brazil and the Amazon "turning Indian" in the 1980s. I initially characterized the transformation of the rubber tappers' movement as a shift from a purely class-based union movement to an identity-based mobilization, as defined by Castells (1996). But this transformation parallels other movements that, like the rubber tappers, are located in specific territories, and share common characteristics.

Chico noted that holding the $1^{\text {st }}$ National Meeting of Rubber Tappers in Brasília and creating the CNS aimed to make government and the public aware that the rubber tappers were not phantasms of the past, but still existed. While alliance between indigenous peoples and rubber tappers was surprising to many, in light of the bloody history of enmity between them, indigenous peoples had at least fifteen years of experience in several forms of struggle to "control the cultural [and political] terms of collective identity and the means to represent and reproduce it" (Turner, 1991, p. 312). Reigning policy prior to the 1988 Constitution and the popular academic theory underpinning it held that indigenous peoples were fated to disappear as distinct societies and cultures (which policy viewed as a desirable outcome) (Ribeiro, 1970). When the National Indian Foundation (FUNAI) was created in 1968 to replace the moribund Indian Protection Service, indigenous groups all over Brazil were regarded as having already lost any recognizable indigenous identity and become "caboclos" or "camponeses" (peasants) ("submerged" indigenous ethnicities, as Viveiros de Castro put it (2006)). An important school of Brazilian anthropology regarded becoming peasants or "proletarianization" as the inexorable and inevitable fate of the Indians (Viveiros de Castro, 1999, p. 18). In fact, the indigenous population was probably at its nadir in the mid- $20^{\text {th }}$ century - the military overseers of FUNAI believed Darcy Ribeiro's indigenous census, which concluded that the population in 1957 was between 68,100 - 99,700 (Ribeiro, 1970, p. 291) - and so believed that the remaining, and waning, indigenous population could be easily accommodated in restricted territories until such time as its assimilation concluded. But, with the publication of the Estatuto do Índio in 1973, and its reiteration of the longstanding constitutional right of indigenous peoples to the lands they traditionally occupied, territorial demands proliferated, including by groups regarded as "caboclos" or "acculturated," such as the Macuxi and Wapixana in Roraima or the several peoples of Acre. The military, in response, proposed the "emancipation" of "acculturated" Indians - that is, using a list of criteria that would allow FUNAI to legally define who was and wasn't Indian, according to outmoded evolutionist principles, and cease to bear any responsibility for the "acculturated" Indians. The "emancipation" project was vehemently opposed by the indigenous peoples and anthropologists - but also, surprisingly, by many from the urban middle class, who supported indigenous land rights in opposition to the military, and was eventually defeated. The demarcation of indigenous lands proceeded - and efforts to discriminate "real" from "acculturated" Indians would continue until the end of the military dictatorship. 
The theory at the root of the assimilationist policies of the Indian Statute and the project of "emancipation," Darcy Ribeiro's “ethnic transfiguration," defined the pathway through which "tribal" Indians would inevitably lose all ethnic and cultural specificity and become "generic Indians," Indians only in contrast to whites or "civilizados." The affinity is patent between this view and Celso Furtado's or the 1985 Regional Plan for Agrarian Reform's understanding of extractivism as an archaic relic of a bygone stage in human development. Ribeiro's theory obviously has a real historical basis - the expansion of western, market based societies since at least the $16^{\text {th }}$ century and continuing through present day globalization has destroyed and dislocated innumerable peoples and societies previously beyond its borders. Following Rosa Luxemburg, Almeida (2012, p. 5) argues that expanding capitalism predatorily feeds on and destroys the non-capitalist regimes on its peripheries. But, "there are always tendencies operating in contrary directions - on the one hand in the direction of homogenization, and on the other, toward new distinctions" (Levi-Strauss, 1978, p. 20, apud Sahlins, 1997, p. 57). The histories of the Indians and rubber tappers from Chico Mendes' day to the present constitute a powerful example of the trend toward new distinctions.

Indigenous peoples, with the promulgation of the 1988 Constitution, won recognition of their socially and culturally distinct ethnicities and permanent, inalienable rights to the lands they traditionally occupied. Not only have indigenous people to date won official legal recognition to about $23 \%$ of the Amazon, but dozens of previously submerged or apparently extinct or unknown ethnicities - starting in the 1970s in the very region held to be the paradigm of the irreversible, inexorable process of transformation of indigenous peoples into peasant communities, northeastern Brazil - have emerged and won recognition of territories (Viveiros de Castro, 2006). The self-declared indigenous population grew from 306,245 in 1991 to 734,131 in 2000, then 817,963 in 2010 (Azevedo, 2011) - far more than explicable by birthrate.

Chico Mendes and the rubber tappers became part of the same "quintessentially modern struggle to control the cultural [and political] terms of collective identity and the means to represent and reproduce it" (Turner, 1991, p. 312) in the moment that they decided that defense of the colocações was the central objective of their movement, leading them to ally with the Indians and environmentalists and eventually create the extractive reserves. We should recall that the initial connection was to indigenous lands and indigenous peoples' collective, inalienable rights to their territories. As Cunha \& Almeida (2004) note, the idea of collective use rights to land, owned by the federal government, ineligible for individual subdivision or sale, appealed strongly to the socialist rubber tapper leaders, and consequently became the basis of the legal figure of the extractive reserve, first through the National Institute for Agrarian Reform's (INCRA) "Extractivist Settlement Project" and subsequently the Extractive Reserve created by the Brazilian Environmental Institute (IBAMA). This was to have major consequences for the rubber tappers, but also for rural populations across Brazil in the 1990s. For, if the rubber tappers in some sense "turned Indian" in the 1980's, rural populations all over Brazil subsequently turned extrativista. As Carneiro da Cunha \& Almeida elucidate (2004), in the wake of the rubber tappers a plethora of "traditional populations" proposed themselves as candidates for extractive 
reserves and defense of the forest - ribeirinhos, [artisanal riverine fishing communities]; coastal artisanal fishers; Brazil nut gatherers; collectors of babassu palm nuts; and more. The Transamazon family farmer/colonist movement followed the same trajectory, proposing family agriculture as a potentially sustainable alternative to uncontrolled deforestation and illegal occupation of public lands, and ultimately successfully advocating for the creation of the Terra do Meio reserves mosaic. (see Allegretti, 2002, p. 709). All of these movements have defined themselves in large measure by opposing their traditional, non-market, or non-industrial land uses to the "official," government-sponsored development model (Schwartzman et al., 2010). Inasmuch as today, even the leaders of the National Confederation of Agriculture and the Minister of Agriculture argue that large-scale farmers and agribusiness are forest defenders (very differently than in Chico Mendes day), the social movements have conceptually, albeit in a still unstable sense, transformed the idea of "development."

In the early 2000's the CNS changed its name to the National Council of Agro-Extractivists, in light of the actual range of economic activities of its constituents (although keeping the historic acronym CNS). There are now various configurations of the original extractive reserve concept: the Sustainable Development Reserve, under the Chico Mendes Institute for Biodiversity (ICMBio) and the original Extractive Reserve; as well the Agro-Extractivist Settlement Project and Sustainable Development Project under the authority of the National Institute of Colonization and Agrarian Reform (INCRA). All of these lands reserved for agro-extractivist or traditional populations reflect, as Carneiro da Cunha \& Almeida (2004) put it, the local peoples' willingness to negotiate provision of forest protection and environmental services in exchange for land rights, social services and access to markets and technology. While the actual terms of the exchange have varied very widely over time and place, adherence to the principle has only grown. All of these territories also, like indigenous lands, are either collectively held, or in principle managed on common principles (while INCRA's settlement projects are in theory supposed to result in individual settler families receiving land titles, in practice this rarely occurs). The proliferation since the latter part of the $20^{\text {th }}$ century of territorially-based ethnicities and identities, secured through collective rights, and contributing directly to forest protection and socio-biodiversity - from Indians, to rubber tappers, extractivists, traditional populations, agro-extractivists and family farmer protagonists of large-scale forest protection in indigenous territories and protected areas - is in some measure the basis of Viveiros de Castro's provocative but allusive slogan, "In Brazil, everyone is Indian, except for those that aren't" (2006). It is at any rate clear that Chico and Wilson Pinheiros' option for the defense of the colocação ultimately catalyzed and gave voice to a much broader process (which they both articulated and reflected), mirroring ethnic reaffirmation and ethnogenesis, that has transformed the concepts of both development and conservation in the Amazon. The issue is not only that the extractive reserves concept multiplied. Protected areas inhabited and managed by local communities, once conceived as an exception in the portfolio of protected areas, now appear as the rule, either de jure, with "sustainable use protected areas" or de facto, as we come to recognize that most if not virtually all "strict protection" areas in the Amazon are in fact inhabited by 
traditional and/or indigenous populations - whose historical occupation is to a greater of lesser degree responsible for the preservation of today's ecosystems (Schwartzman et al., 2013).

None of these populations live outside of the globalized market economy (even isolated indigenous groups are increasingly surrounded by and under pressure from loggers, miners, and infrastructure and extractive industry projects). Few if any propose to live outside of the market economy, even while envisioning radically changed relations to it. Herculano Oliveira Filho, from Riozinho do Anfrísio Extractive Reserve in Pará voices a sentiment that in my experience is very general among both indigenous and traditional peoples: "I don't want to live in the city, because to live there you need so much money. I want a garden, here in the Reserva - I want to be able to eat as much fish as I pull out of the river, and feed myself, and my family. But I also want enough money to go to town whenever I need to, and buy what I need" (Schwartzman, 2018, p. 6). The collective goods that are indigenous territories, extractive reserves and their analogues are on one hand a buffer against the predatory expansion of the market, and the socio-cultural, economic, and ecological diversity has allowed their inhabitants to in some measure control and limit their dependence on the market, and form the basis of a vision for the reordering of these populations', and their territories' relations to the market and the state. The alliance with national and international environmental movements conceived and initiated by Chico Mendes, Ailton Krenak and others, based in the recognition that socio-biological diversity is necessary to the universal, global values of the environmental movement, is central to this vision.

Herein lies the innovation of Chico and Ailton's, and their multiple successors' vision. The idea of collective rights to territories and negotiating protection of socio-cultural, economic and ecological diversity in exchange for access to twenty-first century technology, social services and to markets on terms that local peoples can in some measure control, ${ }^{8}$ is in principle applicable and potentially of enormous global importance far beyond the Amazon, Brazil and the Americas.

Anthropologist Michael Dove, in a comprehensive review of anthropological writing on the concept of indigeneity and environmental politics, catalogues theoretical and political concerns of anthropologists' and indigenous peoples' uses of indigeneity. Many, he notes, are concerned by the political implications of the concept, as they construe it:

"I fear there is a heavy price to be paid for the emphasis ... on cultural purity, continuity, and alterity. Such efforts at cultural conservation make no room for the vast majority of the world's poor, who live on the margins of subsistence and the most degraded ecological conditions but who cannot claim to be 'indigenous people' in the limited definition accorded the term." (Gupta, 1998, p. 289, in Dove, 2006, p. 5).

While it is the case that the identification of particular ethnicities with specific geographies has had very different origins and socio-political consequences - some hardly beneficial -- to peoples in different regions of the world (Schwartzman et al.,

\footnotetext{
${ }^{8}$ Note that while extractive reserves and similar environmentally protected areas in Brazil are in principle (and by law) conditioned on this bargain, indigenous territories are constitutionally guaranteed based on indigenous peoples' historical connection to pre-Columbian populations that predate the Brazilian state. (c.f. Carneiro da Cunha \& Almeida, 2004)
} 
2013), in reality "cultural conservation" has always meant ethnogenesis and cultural transformation and creation, as we have seen of the Amazon and more broadly (Sahlins, 1997; Appadurai, 1991). But also, Chico's vision could allow many more people than rural Amazonians to "turn Indian." We know that the indigenous territories and protected areas of the Amazon alone store enough carbon to very significantly affect the future of the global atmosphere and climate (Walker et al., 2014), all the more so for the indigenous territories and protected areas of the tropics. There is burgeoning scientific consensus that stopping deforestation, restoring degraded forests and other lands, and improved land use management are not only necessary to control climate change, but offer the best nearer-term opportunity to reduce greenhouse gas pollution at a scale sufficient to avert catastrophic climate change while we, it is to be hoped, transform the global energy matrix (Houghton et al., 2017; Griscom et al., 2017; Seymour \& Busch, 2016). The UN Paris Agreement and the international civil aviation sector's commitment to neutralize emissions after 2020, California's emissions control regulations and some 50 other jurisdictions' similar measures suggest that, the Trump administration to the contrary, much of the rest of the world understands the importance of reducing emissions at scale, and quickly. The vast majority of the world's poor people (especially those in the most degraded ecological conditions) and the global atmosphere could benefit enormously by at scale investments in clean energy, restoration of degraded lands, high-value, low-carbon agriculture, zero-deforestation rural development and improved land management. The model of collective rights - whether to land, water, clean air, health or education - coupled with adequate support for access to technology, markets and knowledge, could in principle enable the vast majority of the world's poor to become the Indians and rubber tappers of the global commons. This may be what Chico meant when he famously said, "At first I thought I was fighting to save the rubber trees, then that I was fighting to save the Amazon forest. Now I realize that I'm fighting for humanity" (Haberman, 2016, p. 1).

\section{Acknowledgements}

I would like to thank Mary Allegretti, Marianne Schmink and Lucia Helena Oliveira Cunha for organizing this publication, and two anonymous reviewers for their helpful comments.

\section{References}

Allegretti, M. H. Chico Mendes: ten years before. In: Schwartzman, S. (Ed.). From the ashes: reflections on Chico Mendes and the future of the rainforest. Washington, DC: Environmental Defense Fund and National Wildlife Federation, 1998.

Allegretti, M. H. A Construção de Políticas Ambientias: Chico Mendes e o Movimento dos Seringueiros. Brasília, Dissertation (Ph.D. in Sustainable Development) - University of Brasília, 2002.

Almeida, M. W. B. de. Sociodiversidade e desenvolvimento: Considerações entre centro e margem, 2012. Available at: $<$ https://mwba.files.wordpress.com/2010/06/almeida-2012-sociodiversidade-e-desenvolvimento.pdf $>$. Accessed on: apr. 2018.

Appudarai, A. Global ethnoscapes: notes and queries for a translational anthropology. In: R. G. Fox (Org.). Recapturing anthropology. Santa Fe: School of American Research Press, 1991. p. 191-210. 
Azevedo, M. M. O censo 2010 e os povos indígenas. In: Ricardo, B.; Ricardo, F. (Eds.). Povos indígenas no Brasil 2001/2005. São Paulo: Instituto Socioambiental, p. 45-48, 2011.

Browder, J. The limits of extractivism. BioScience, 42(3), 174-182, 1992. doi: $10.2307 / 1311822$

Castells, M. Rise of the network society: the information age: economy, society and culture. Cambridge, MA: Blackwell Publishers, Inc., 1996.

Cunha, M. C. da.; Almeida, M. W. B. Traditional populations and environmental conservation. In: Veríssimo, A.; Moreira, A.; Sawyer, D.; Santos, I. dos.; Pinto, L. P. (Eds.). Biodiversity in the Brazilian Amazon. São Paulo: Editora Estação Liberdade, 2004. p. 182-191.

Dove, M. Indigenous people and environmental politics. Annual Review of Anthropology, 35(1), 191-208, 2006. doi: 10.1146/annurev.anthro.35.081705.123235

Duarte, E.G. Conflitos pela terra no Acre. Rio Branco: Casa da Amazônia, 1987.

Griscom, B. W.; Adams, J.; Ellis, P. W.; Houghton, R. A.; Lomax, G.; Miteva, D. A.; Schlesinger, W. H.; Shoch, D.; Siikamäki, J. V.; Smith, P.; Woodbury, P.; Zganjar, C.; Blackman, A.; Campari, J.; Conant, R. T.; Delgado, C.; Elias, P.; Gopalakrishna, T.; Hamsik, M. R.; Herrero, M.; Kiesecker, J.; Landis, E.; Laestadius, L.; Leavitt, S. M.; Minnemeyer, S.; Polasky, S.; Potapov, P.; Putz, F. E.; Sanderman, J.; Silvius, M. Wollenberg, E.; Fargione, J. Natural climate solutions. In: Proceedings of the National Academy of Sciences of the United States of America. 31 October 2017.

Gupta, A. Postcolonial Developments: Agriculture in the Making of Modern India. Durham, NC, Duke University Press. 1998. cited in Dove, M. Indigenous people and environmental politics. Annual Review of Anthropology, 35(1), 191-208, 2006. doi: 10.1146/annurev.anthro.35.081705.123235

Haberman, C. The Lasting Legacy of a Fighter for the Amazon. New York Times Retro Report, 27 November 2016. Available at: https://www.nytimes.com/2016/11/27/ us/chico-mendes-amazon-retro-report.html accessed July 25th, 2018.
Homma, A. K. O. Plant extractivism or plantation: what is the best option for the Amazon? Estudos Avançados, 26(74), 167-186, 2012. doi: 10.1590/S0103-40142012000100012

Houghton, R. A.; Byers, B., Nassikas, A. A. Negative emissions from stopping deforestation and forest degradation, globally. Global Change Biology, 24(1), 1-10. 2017. doi: 10.1111/gcb.13876

Krenak, A. In Pachalski, F.; Allegretti, M.; Pereira, M.B.; Almeida, M. W. B. de; Balcão, N. (Eds.). Chico Mendes. São Paulo: Sindicato de Trabalhadores Rurais de Xapuri, Conselho Nacional de Seringueiros (CNS); São Paulo: Central Única dos Trabalhadores (CUT), 1989.

Levi-Strauss, C. Myth and Meaning. New York, Schocken, 1978, cited in Sahlins, M. O "pessimismo sentimental" e a experiência etnográfica: por que a cultura não é um “objeto" em via de extinção (parte I). Mana, 3(1), 41-73, 1997. doi: 10.1590/S0104-93131997000100002.

Marx, K.; Engels, F. Manifesto of the Communist Party. Moscow: Progress Publishers, 1969 [1848]. Available at: https://www.marxists.org/archive/marx/works/download/ pdf/Manifesto.pdf

Mendes, C. Interview. Washington, DC. 29 March 1987.

Mendes, C. A luta dos povos da floresta. Palestra promovida pelo Departamento de Geografia da USP e ABG. São Paulo. June 1988.

Mendes, C.; Gross, T. Fight for the forest: Chico Mendes in his own words. London: Latin America Bureau, 1989.

Mendes, C.; Gryzbowski, C. (Org.). O Testamento do Homen da Floresta: Chico Mendes por ele mesmo. São Paulo: FASE, 1989.

Ribeiro, D. Os índios e a civilização. São Paulo: Editora Schwarz Ltda., 1996 [1970].

Sahlins, M. O "pessimismo sentimental” e a experiência etnográfica: por que a cultura não é um "objeto" em via de extinção (parte I). Mana, 3(1), 41-73, 1997. doi: 10.1590/ S0104-93131997000100002.

Schwartzman, G. Amazonian back country: what if the only choice wasn't stay or go? The Daily Yonder, 2018. Available at: < http://www.dailyyonder.com/amazonian- 
-back-country-choice-wasnt-stay-go/2018/03/29/24238/> Accessed on: apr. 2018.

Schwartzman, S.; Alencar, A.; Zarin, H.; Souza, A. P. S.; Social movements and large-scale tropical forest protection on the Amazon frontier: conservation from chaos. The Journal of Environment Development, 19(3), 274-299, 2010. doi: $0.1177 / 1070496510367627$

Schwartzman, S. Seringueiros defend the rainforest. Cultural Survival Quarterly, (10)2, 1986. Available at: https:// www.culturalsurvival.org/publications/cultural-survival-quarterly/seringueiros-defend-rainforest-amazonia

Schwartzman, S.; Villas-Bôas, A.; Ono, K. Y.; Fonseca, M. G.; Doblas, J.; Zimmerman, B.; Junqueira, P.; Jerozolimski, A.; Salazar, M.; Junqueira, R. P.; Torres, M. The natural and social history of the indigenous lands and protected areas corridor of the Xingu basin. Philosophical Transactions of the Royal Society B, 368(1619), 1-12, 2013.

Seymour, F.; Busch, J. Why Forests? Why Now? Washington, DC: Center for Global Development, 2016.

Simons, M. Brazilian who fought to protect Amazon is killed. The New York Times. December 24, 1988. Available at: < https://www.nytimes.com/1988/12/24/world/ brazilian-who-fought-to-protect-amazon-is-killed.html $>$. Accessed on: apr. 2018.

Terborg, J. Requiem for Nature. Washington, DC: Island Press. 1999.

Turner, T. Representing, resisting, rethinking: historical transformation of Kayapo culture and anthropological consciousness. In: Stocking, G. (Ed.). Colonial situations: essays on the contextualization of ethnographic knowledge. Madison: University of Wisconsin Press, 1991. p. 285-313.

Villas-Bôas, A.; Guerrero, N. R.; Junqueira, R. G. P.; Postigo, A. Xingu: história dos produtos da floresta. São Paulo: Gráfica EGB, 2017.

Viveiros de Castro, E. Etnologia Brasileira. In: Miceli, S. (Org.) O que ler na ciência social brasileira (1970-1995). Volume I: Antropologia. São Paulo: Editora Sumaré/ANPOCS, 1999. p. 109-223.

Viveiros de Castro, E. No Brasil, todo mundo é índio, exceto quem não é. In: Ricardo, B.; Ricardo, F. (Eds.)
Povos indígenas no Brasil 2001/2005. São Paulo: Instituto Socioambiental, p. 45-48, 2006.

Walker, W.; Baccini, A.; Schwartzman, S.; Ríos, S.; Oliveira-Miranda, M. A.; Augusto, C.; Ruiz, M. R.; Arrasco, C. S.; Ricardo, B.; Smith, R.; Meyer, C.; Jintiach, J.C.; Campos, E. V. Forest carbon in Amazonia: the unrecognized contribution of indigenous territories and protected natural areas. Carbon Management, 5(5-6), 479-485, 2014. doi: 10.1080/17583004.2014.990680

Zarin, H. L. Making place and identity in the interstices: ribeirinho landscapes in the Terra do Meio, Para. Dissertation (Ph.D. in Anthropology) - University of Florida, 2010. 